\title{
Exploration of Physics Concepts Based on Local Wisdom Kolecer Traditional Games
}

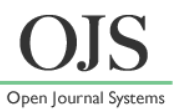

\author{
Mohammad Imam Sholahuddin, Setyo Admoko* \\ Department of Physics, Faculty of Mathematics and Natural Sciences, Universitas Negeri Surabaya, Indonesia \\ *Email: setyoadmoko@unesa.ac.id
}

DOI: https://doi.org/10.33369/pendipa.5.1.70-78

\begin{abstract}
Teachers' perceptions in developing learning are needed to help students more easily capture information from the learning activities undertaken. One way that can be applied is by connecting learning materials with the local wisdom of the surrounding environment or commonly known as ethnoscience. Indonesia is a country rich in local culture in every region. Therefore, it is important for the nation's future generations to protect and preserve what already exists, for example by linking local culture to physics learning materials. The purpose of this study was to determine the potential for any physics concepts that exist in traditional kolecer games that can be applied to learning physics and everyday life. This type of research is the Narrative Review. Based on the research results, it was found that there was a potential application of physics concepts to local wisdom (ethnoscience) in the traditional "kolecer" game, these physics concepts were in the matter of equilibrium, pressure, Newton's first and second law, work and energy, kinetic energy, and circular motion. It can be concluded that the application of local wisdom-based learning can help students easily grasp the material provided by the teacher and make learning more meaningful, especially on local wisdom of traditional kolecer games.
\end{abstract}

Keywords: Narative Review, Ethnoscience, Kinetic Energy, Kolecer.

\section{INTRODUCTION}

In today's modern era, the swift flow of globalization has eroded various kinds of national values. Students are more interested in foreign cultures than their own national cultures (Rosadi et al., 2019). This can be seen when there is a sense of pride in yourself when using or owning a foreign product, compared to products originating from your own country. This needs to be a concern when a sense of love for one's own nation is lacking and enters the value of education in Indonesia

According to (Makhmudah et al., 2019) education in Indonesia on average still uses the Dead Knowledge learning system, which means transferring knowledge and understanding to students using the memorization method (textbookish), so that the learning received by students does not integrate with culture and activities. Existing society.

This is also in accordance with the opinion of (Suastra, 2013) in general, physics learning has a tendency (1) lack of perception of real-life and often teach calculations, (2) the assumption that physics lessons are difficult so that students become afraid and do not comfortable with learning, (3) lack of encouragement for students to think critically and creatively, (4) rarely practice solving problems that exist around them and do not instill the value of local wisdom around students.

(Satriawan \& Rosmiati, 2016) explained that the application of contextual based learning principles to local wisdom will be able to make learning received by students more meaningful because students will carry out activities scientifically and gain experience by applying real and independent learning, not only teachers who transfer knowledge towards students.

Wisdom, in terms of etymology, is the ability a person has when responding to an event, object, or any situation using his or her mind. Whereas local (local), in this case, shows a space where there is an interaction of events or situations that are happening. In this case, local wisdom is a norm that exists and applies in a society that can also be believed in its truth and becomes a guide in taking action and behavior (Mardotilah, 2016).

Local wisdom describes how to act in response to specific changes in the local 
physical and cultural environment (Bahtiar, 2016). Every region in Indonesia has local potential which is an asset of natural, human, technological, and cultural resources that must be preserved and developed to improve a more civilized life. The functions of local wisdom include: a) Local wisdom functions for the protection and preservation of natural resources; b) Local wisdom serves to help develop human resources; c) Serves as the development of culture and science; d) Serves as a form of advice, belief, literature, and taboo (Faizah et al, 2017)

Kolecer or bamboo propeller is a traditional game from Sundanese, West Java. This game from Cibuluh Village, Tanjungsiang District, Subang Regency (Susanti \& Nurtania, 2017). In ancient times, the retailer created when farmers looked after their fields and felt lonely, so they finally made it by entertainment. When the propeller is hit by a strong wind, the propeller will spin faster and that's when the collector makes a loud sound. Sometimes kolecer use by farmers to repel birds that land on rice and as a rodent repellent that is usually paired on the edge of rice fields. Apart from birds, rats roaming the fields and disturbing farmers' crops will not feel at home with the sound that comes out of the kolecer

This traditional game focuses on a windmill or bamboo propeller. Apart from being used for toys and also tools to help farmers repel pests that interfere with crops, this windmill has many benefits in everyday life, one of which is being used by salt farmers on the north coast of Java Island to pump water or move water from ponds to pool. This is due to the remote access to electricity in salt farming so it is not possible to pump water from a power source (Deo, 2020).

The advantages of this traditional game can use a learning tool or method (Agustini, 2020). Where physics is included in naturebased learning or commonly referred to as Natural Sciences (IPA). In science learning, there is a characteristic that is different from other lessons. Students require to know for themselves the concepts that exist in learning materials through various activities such as discussions, observations, experiments, or practicum and also be able to solve problems around them.

Physics is a natural science that can explain observable phenomena based on human experiences, rational thoughts, and detailed experimental activities (Makhmudah et al., 2019). it can prove that physics is very close to everyday life. Every phenomenon that exists in everyday life, whether it has happened or is currently happening, is related to learning physics. So, it should be significant to study and study local wisdom scientifically, to be able to foster self-awareness to maintain, preserve, and develop the potential that exists in the surrounding environment.

In this study, the author aims to determine the potential in traditional kolecer games related to the concept of physics. The benefit from this research can know the potency of kolecer games by observing existing physics concepts and exploring the results of research to serve as insight and scientific literacy for readers that are applied in everyday life, especially for the continuity of learning physics.

\section{METHOD}

The research method used in this article is the Narrative Review. This type of Narrative Review research is the same as the literature study method can interpret as a method of collecting data from research objects from various literacies and concluding into one study. The data collection methods used were literature and observation. The observation activity carried out was the indirect observation, namely by making visual observations in the form of videos and pictures. The study material was studied as a form of kolecer game (windmill), where the researcher analyzed the potential of any physics concept contained in the traditional Kolecer game.

The data collection method by journal reviews and observation from social media, such as youtube. The data has obtained from various sources are then analyzed and adjusted to the study topic used, like an exploration of the concept of physics. So, the results of the analysis from various sources are summarized and assembled into a finding that can be useful for teachers and students in the process of learning physics.

\section{RESULT AND DISCUSSION Physics Learning}

Physics is a science that studies various physical events that are also related to how natural events can occur that analyzed in a measured manner through observation and research. Physics is also a science that requires 
facilities and infrastructure to support learning. Therefore, studying physics now does not have like memorize formulas, but a learning process with an understanding of the factual process and its application in everyday life.

Every subject in physics requires an appropriate and effective perception in interactions with students so, that learning messages are easily conveyed and accepted by students (Rosadi et al., 2019). Apperception is needed by teachers when starting a lesson by linking learning materials with things around students. Will increase the ability to catch students quickly and precisely when in the learning process. When a perception has been conveyed by the students of the study will have a special meaning by the students so that the students did not have misconceptions about a matter

\section{Ethnoscience}

Ethnoscience is combine from original science that contains everything according to scientific and real knowledge with the environmental conditions of society that come from social facts and hereditary beliefs. Ethnoscience has a scope limitation that is in the fields of science, agriculture, ecology, medicine, and also the relationship of flora and fauna. The existence of the discovery of ethnoscience cannot be separated from the discovery of knowledge obtained by trial and error by various previous scientists to increase the potential of local knowledge that needs to be developed in a learning process (Novitasari et al., 2017).

In the physics learning model, ethnoscience is an educational innovation that links socio-cultural conditions with scientific technology (Handhika \& Kurniadi, 2019). Many things happen in social life, especially in the socio-cultural is conditions, where each region has a different culture. That is one of the educational innovation strategies because the socio-cultural conditions are very close to the students.

Learning the application of physics concepts can be done by exercises of a draft by knowing the relevant applications in everyday life phenomena. Local culture can use a learning resource, especially in physics learning needs physical and real applications to facilitate student understanding. The concept of learning derived from local culture are also able to improve students' skills in analyzing the environmental conditions associated with the study of the science knowledge of students (Arlianovita et al., 2015)

\section{Kolecer Traditional Games}

This research will connect physics learning with the socio-cultural conditions in West Java, in the case will be discussed is local wisdom in traditional kolecer games.

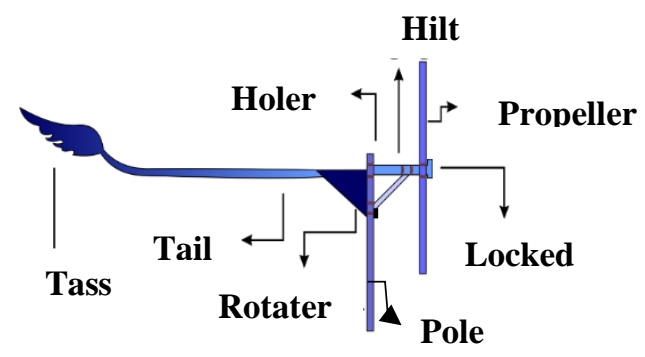

Figure 1. Kolecer

(Nurusholih \& Permana, 2018)

Kolecer is an artifact originating from West Java. This artifact is in the form of a traditional game that can find ranging from Kuningan, Subang, to sumedang (Nurusholih \& Permana, 2018). This game is a tradition passed down from generation to generation from ancestors. Kolecer or commonly referred to as windmills made of bamboo sticks which as propellers.

The name and function of kolecer parts is:

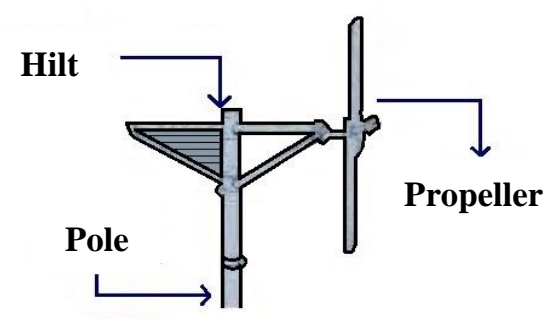

Figure 2. Part of kolecer

(Nurusholih \& Permana, 2018)

According to (Nurusholih \& Permana, 2018), there are three parts of the retailer. First is a pole, the main supporting from kolecer can stand upright consists of several bamboos then tied together and made into a pole. Second is Jajabing, this section serves to rotate the kolecer. The third is Solobong, which is a part of the collector that functions as a hook for the shaft so, that the collector can rotate. These three parts have a very close relationship, if one part does not work, the retailer will not rotate 
properly and even the retailer will not rotate. The philosophy of the Sundanese, the three parts of this kolecer are by the Tritangtu Sundanese it means determination, words, and lamp or compassion and compassion. Pole and handle on the collector are deliberately not separated. The pole becomes the base or support of the collector and the handle connected to the propeller. The position of the handle can rotate horizontally according to the direction of the wind, and the propeller will rotate vertically when hit by the wind.

The traditional kolecer game focuses on its windmill system. That propeller is a tool that utilizes the power of wind-energy to convert it into mechanical energy (Yuliana, 2019). In this case, the energy from the wind is needed by the game so that the propeller can rotate. The West Java region has many plateaux so, Sundanese people play this game of kolecer in the highlands. The higher the position of the object, the higher the air pressure experienced by that object.

This traditional game requires wind energy as it's the first energy. According to (Habibie et al., 2011), the wind is moving air because there is a difference in pressure on the earth's surface so, the air moves from areas with high air pressure to lower air pressure. That is results in differences in air temperature with differences cause's differences in air pressure between regions.

\section{Teoritical of Physics Concept}

This research discusses the potential of any physics concepts that exist in traditional kolecer games. In physics, concepts can observe from this game of kolecer (windmill), including:

\section{Equilibrium}

Making this traditional kolecer game cannot be arbitrary, that needs unique technique so that when playing the game it can move properly. One of that technique of making a retailer by paying attention to the balance between the sides of the propeller being used.

The number of side propellers used for this game varies depending on the person who made it. However, on average use the number of propellers 2-3 sides only. Each side must have the same length, as well as the same type of wood to have the same weight between the sides.

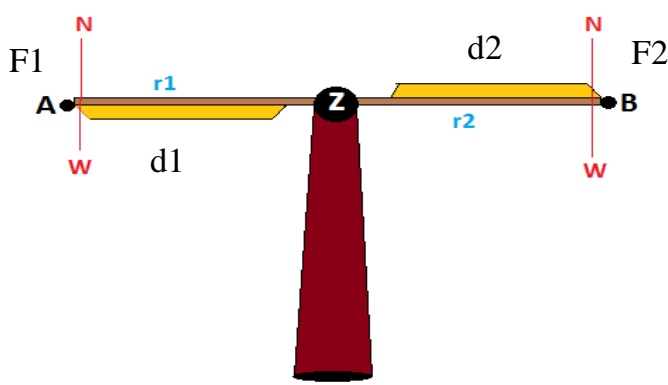

Figure 3. Balance of the propeller side

On the propeller above, there are points $\mathrm{A}, \mathrm{Z}$, and $\mathrm{B}$. Point $\mathrm{Z}$ is the balancing point of both sides. The length of the propeller can be found by the point $\mathrm{A}-\mathrm{Z}$ and point $\mathrm{Z}-\mathrm{B}$, where both sides are the same as the value of $r_{1}$ and the length of Z-B is $r_{2}$. The side of the propeller has mass, so when the propeller is placed towards the top of the collector handle, the propeller has a weight value $(\vec{w})$ because it is influenced by the gravitational force $\vec{w}=$ $m \cdot g$.

Two-dimensional objects are said to be balanced if they have the criteria that $\overrightarrow{F_{x}}=0$ and $\overrightarrow{F_{y}}=0, \vec{F}$ is the value of the force an object. In the equilibrium process, there is an application of Newton's First Law, namely:

$$
\Sigma \vec{F}=0
$$

When an object experiences equilibrium, it means that there is a moment of force $(\vec{\tau})$ which applies to the object in this case at the collector. Where the moment of force is the product of the moment arm $(d)$ and the force $(\vec{F})$. So that there is a connection between Newton's First Law and the moment of force, namely:

$$
\begin{aligned}
& \Sigma \vec{F}=0 \\
& \Sigma \vec{\tau}=0 \\
& -\overrightarrow{F_{2}} \cdot d_{2}+\overrightarrow{F_{1}} \cdot d_{1}=0 \\
& \quad \overrightarrow{F_{1}} \cdot d_{1}=\overrightarrow{F_{2}} \cdot d_{2}
\end{aligned}
$$

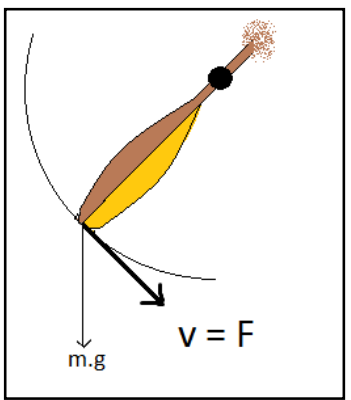


Figure 4. The propeller when rotating

After the propeller experiences movement with its axis, the propeller will also maintain its equilibrium, or what is commonly called the moment of inertia $(I)$. The movement of the propellers forms a field that is circular and must have a value of $r$ or the radius of the circle, in this case, is the radius of the circle. The moment of inertia is obtained by the equation:

$$
I=m \cdot r^{2}
$$

When the object is at first stationery then experiences movement, the object experiences acceleration from its displacement. This is by Newton's Second Law, where when an object with mass is influenced by an external force, the object has an acceleration, namely:

$$
\Sigma \vec{F}=m \cdot a
$$

Then the equation is associated with the kolecer movement so that the equation is obtained:

$$
\begin{gathered}
\Sigma \vec{F}=m \cdot \vec{a} \\
\vec{F}=m \cdot(\alpha \cdot R) \\
\vec{F} \cdot r=m \cdot \alpha \cdot r^{2} \\
\vec{F} \cdot r=\left(m \cdot r^{2}\right) \alpha
\end{gathered}
$$

From this equation, it knowns that $\vec{F} . r$ is the value of the moment of force and $m \cdot r^{2}$ is the value of inertia. In this case, it shows each a link between the force moment and the moment of inertia. So the above equation can be written as follows:

$$
\vec{\tau}=I . \alpha
$$

\section{Pressure}

The variety of this kolecer game size, some are small, medium, and large. The way to play it is different, the small ones are enough to hold by hand while the medium and large ones are usually done by planting the kolecer supporting rods into the ground and some are tied to the trees.

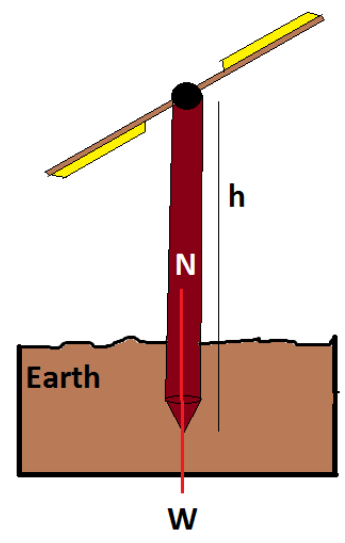

Figure 5. Playing kolecer by planting it

The picture above is a way of playing kolecer by planting the supporting rods from the kolecer into the ground. That is the application of the concept of physics to pressure. The pressure experienced by the logs on the earth serves to maintain the balance of the kolecer rods so that they remain solid when the windmill has turned. Self-pressure is formulated by:

$$
P=\frac{\vec{F}}{A}
$$

Where the pressure is influenced by the force $(\vec{F})$ acting on the collector and also the surface area $(A)$ of the kolecer support rod.

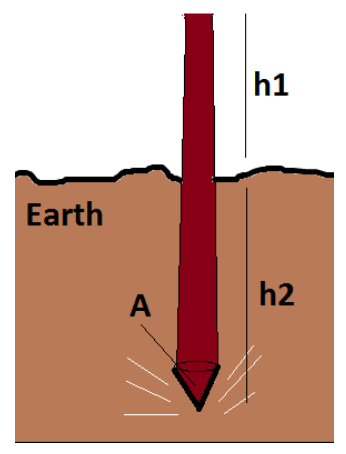

Figure 6. Process of pressing logs to the ground

The surface area in this kolecer game is shown in the figure, namely the end of the support rod that is tapered or pointed. In this case, it can be analogous to the area of the blanket from the cone shape and the area of the cone blanket in the area of the rectangle. It's mean $A=p . l$.

The pointed end of the stem will make it easier to insert the support rod into the ground. In the figure, it is known that the value of $h, h_{1}$ indicates the height of the support rod above the 
soil surface and $h_{2}$ is the length of the support rod that enters the soil. The greater the $h_{2}$ value or which means the larger the length of the part of the kolecer support rod that is in the ground will be able to make the support rod stronger when the propeller is blown.

$h_{1}$ is the height of the stalks above the ground. The greater the $h_{1}$ value, the more impact on the rotation of the propeller. The higher the support rod, the higher the position of the kolecer, and the higher the wind energy produced. The highest of kolecer affected the power of air pressure that affects the object. Air pressure can formulate as follows:

$$
P_{h}=\left(\frac{P_{u}-h}{100}\right) c m H g
$$

\section{Work and Energy}

The traditional game of kolecer requires the main energy in the form of wind energy. This source of wind energy is needed by windmills to move the blades so it can rotate. That is a potential concept of physics means that the presence of energy can affect the movement by an object. Wind energy makes the propeller move and rotate, which means that the mechanical performance of an object is influenced by external forces or energy acting on the object. From visual observations via video, it was found that when the blades of the collector (windmill) began to move, another energy emerged, namely sound energy generated from every rotation of the windmill system in this collector game. The faster the rotation of the propeller, the louder the sound will be

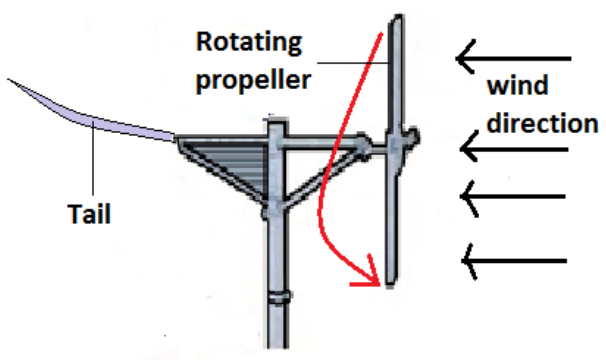

Figure 7. Process Work and energy of windmill

In this case, it can call that there is a potential for more physical concepts besides wind energy to become the energy of motion, namely sound energy. So, this movement of the propellers is affected by wind energy with sound energy is affected by wind energy, sound in the kolecer game is caused by the breeze hitting the propeller then continues back so that it hits the tail of the kolecer made of coconut leaves.

4. Kinetic Energy

Windmills are energy conversion machines that can convert wind energy toward useful energy in the form of a rotating shaft wind moves at a certain speed that converts energy in the form of kinetic energy. Kinetic energy occurs the wind hits part of the propeller and makes the propeller rotor of the windmill move and rotate.

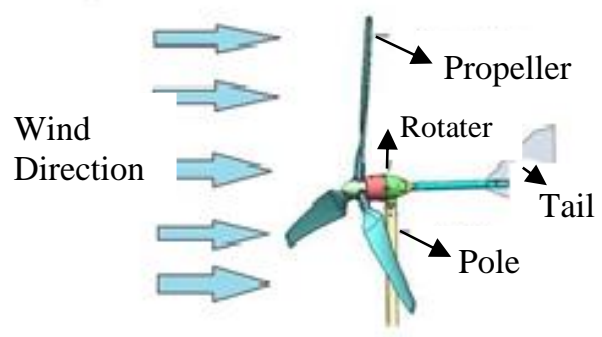

Figure 8. Process of kinetic energy in windmills

Kinetic energy is the product energy because a response in the form of movement in a windmill game from the wind that blows and crashes into the propeller causes the propeller to move. The kinetic energy is affected by the velocity $(v)$ and mass $(m)$ of an object so that the following formulations obtained:

$$
E K=\frac{1}{2} m \vec{v}^{2}
$$

Where the Ek means the kinetic energy sought in units (Joules), $\mathrm{m}$ is the mass value of the object in units $(\mathrm{kg})$ then $\mathrm{v}$ is the speed, the speed referred to here is the wind speed in units $(\mathrm{m} / \mathrm{s})$.

The energy produced by wind can calculate using the wind energy power equation, namely

$$
W=\frac{1}{2} \rho A \vec{v}^{3}
$$

According to Mirza et al., (2019), the above equation is used when getting the ideal wind speed and assumes that the wind energy produced can completely transform into kinetic energy.

5. Circular Motion

The Circular motion in this windmill is a type of regular circular motion. It still wheels slowly rotates towards its axis. The mill can move with the help of the wind. Then the wind hits the propeller, the windmill moves, and then makes a sound. Windmills also have linear 
velocity and angular velocity. When a windmill experiences constant speed and speed, the output sound produced by the rotation of the mill will also experience that constant sound frequency

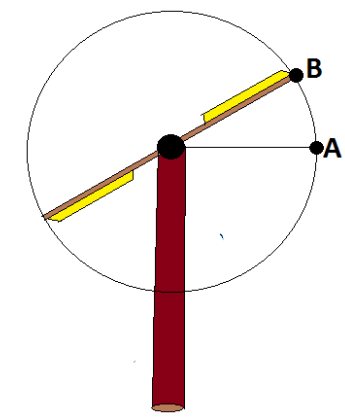

Figure 9. Position movement of windmill

We can observe the rotating motion of the blades in a windmill. The propeller rotates besides the shaft in the center of the wheel, the propeller movement from one position towards the center with rotation reference. The displacement experienced by the propeller associated with circular motion is the angular displacement.

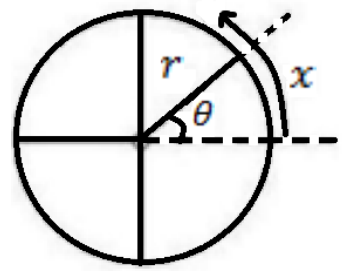

Figure 10. Radian angle measurement

The calculate of the radiant value in angular displacement is compare the linear distance $\mathrm{x}$ between the r-rays (in the picture). $r$ here is the distance between the propellers against the mill shaft. So, get the equation:

$$
\theta(\mathrm{rad})=\frac{x}{r}
$$

A lateral rotation of the propeller is a return to the starting point is equal to the circumference of the circle so, from the above equation is obtained:

$$
\theta(\mathrm{rad})=\frac{2 \pi r}{r}=2 \pi \mathrm{rad}
$$

Besides it, when the propeller rotates, it also has angular velocity. The angular velocity can be found through the calculation of the angular displacement traveled in a certain time, which is called angular velocity. So that it can be formulated as follows:

$$
\vec{\omega}=\frac{\Delta \theta}{\Delta t}
$$

The angle taken in a period of time $\Delta t=T$ and $\Delta \theta=2 \pi \mathrm{rad}$, then the angular velocity experienced by a windmill in a regular circular motion is formulated:

$$
\vec{\omega}=\frac{2 \pi}{T}
$$

Period (T) is the time it takes for the wheel to experience one full of turn $T=\frac{t}{n}$. The unit of the period is seconds or seconds. Then the number of revolutions made by an object in this case the propeller in time units is said to be the frequency value $f=\frac{n}{t}$. Frequency and period are closely related to each other. So, that we get $T=\frac{1}{f}$. Then the equation for the angular velocity is substituted for the equation for the period. So that you get the following formulation:

$$
\vec{\omega}=2 \pi f
$$

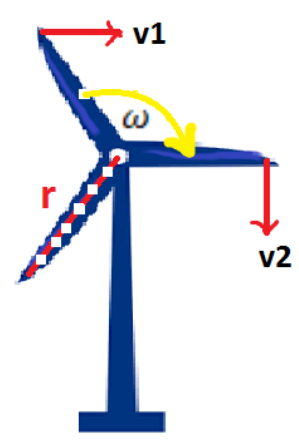

Figure 11. The angular velocity direction

The value of the angular velocity in a regular circular motion is zero. However, the angular velocity has a direction that changes with time and the position of the propeller. This change results in a difference in angular velocity within a certain time interval towards the center or axis of the circle (Pristiadi Utomo, 2017).

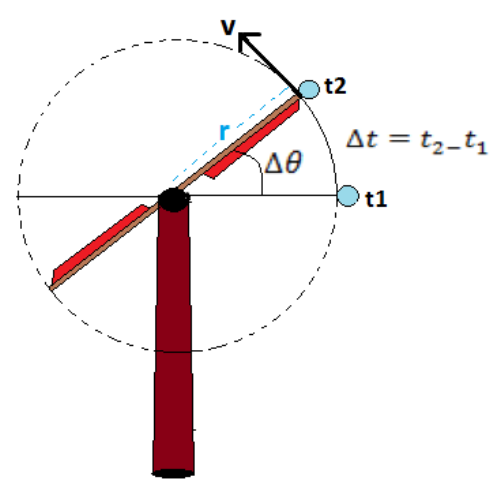

Figure 12. Relation of angular velocity to linear velocity 
Angular velocity and linear velocity are related to the process of rotational dynamics. In (Figure 12), the propeller of the kolecer game has a different position when moving, namely turning. From the initial position to the displacement position has a different time. It can be seen that there is a time that is different from the conditions of the propeller movement, which can be formulated:

$$
\Delta t=t_{2}-t_{1}
$$

It can be seen that the equation of angular velocity $(\vec{\omega})$ is $\vec{\omega}=\frac{\Delta \theta}{\Delta t}$. In the picture, it is also known that the movement of the propellers will form a circular field, where the circle has a value of $r$ or what is called the radius of the circle. In this kolecer game, the $r$ value is the length of the side of the propeller. In terms of angular velocity $(\vec{\omega})$ and linear velocity $(\vec{v})$, it requires a value of $r$ (radius). So that we get the equation:

$$
\vec{v}=\mathrm{r} \cdot(\vec{\omega})
$$

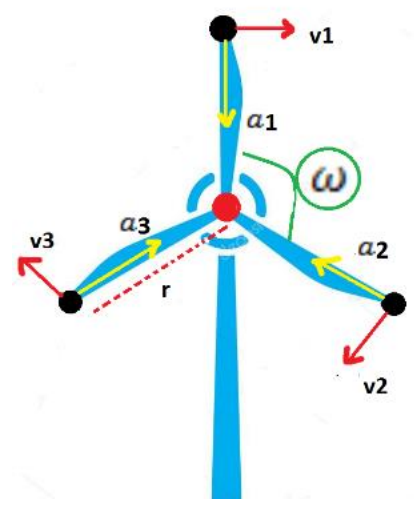

Figure 13. Centripetal acceleration in winmill

In the performance of a windmill that moves on its axis, which is to make a circular motion, there is also an acceleration that works when the blades of the windmill move. The direction of the centripetal acceleration (a) is perpendicular to the angular velocity and points to the center of the movement that is the rotor of the vane. From the explanation (Figure 13), the centripetal acceleration equation is obtained as follows:

$$
\begin{array}{r}
\vec{a}_{s}=\vec{\omega}^{2} \cdot r \\
\vec{a}_{s}=\frac{\vec{v}^{2}}{r}
\end{array}
$$

\section{CONCLUSION}

Based on the results that have been carried out from several analyzes and observations, it concludes that the traditional game kolecer has a lot of potential for the development of physics concepts includes: equilibrium, pressure, Newton's first and second law, work and energy, kinetic energy, and circular motion.

In this research, we conclude that there was a need for innovations by teachers on physics to help students understand the material more easily by connect the physics material based on local wisdom or anything related to student life to get meaning from physics in terms of this in the traditional Kolecer game from West Java.

\section{THANK-YOU NOTE}

In preparing this article the authors would like to thank you for the motivation, input, criticism, and constructive suggestions to:

1) Dr. Munasir, S.Si., M.Si. as the Head of the Physics Department

2) Nadi Suprapto, Ph.D. as the Head of the Physics Education Study Program

3) Setyo Admoko, S.Pd, M.Pd as the supervisor

4) Dr. ZA Imam Supardi, M.Si., and Nadi Suprapto, Ph.D. as a lecturer examiner

5) Ladies and gentlemen and brothebakhrs for all prayers and assistance both material and moral

6) Friends of "Physics Brothers" class of 2017

\section{REFERENCE}

Agustini, F. (2020). Integrasi Nilai Karakter Melalui Permainan Tradisional Tarik Tambang Dalam Pembelajaran IPA. Jurnal Ilmiah Sekolah Dasar, 4(2), 114. https://doi.org/10.23887/jisd.v4i2.24513.

Arlianovita, D., Setiawan, B., Sudibyo, E. (2015). Pendekatan Etnosains dalam Proses Pembuatan Tempe terhadap Kemampuan Literasi Sains. 101-107

Bahtiar, D. (2016). Bahan Ajarberbasis Kearifan Lokal Terintegrasi Stm (Sains, Teknologi, Dan Masyarakat) Pada Mata Pelajaran Fisika. Seminar Nasional Pendidikan 2016 ISSN: 2527 - 5917, Vol.1.

Christmas Deo, S.D., (2020). Untuk Kerja Kincir Angin Petani Garam Demak Empat Sudut Dengan Variasi Panjang. Skripsi.Universitas sanata dharma. 
Faizah, S., Supriadi, B., Bachtiar, R.W.(2017). Kajian Gerak Melingkar Pada Sepeda Sebagai Rancangan Bahan Ajar Fisika Sma. Seminar Nasional Pendidikan Fisika 2017 UNEJ. ISSN: 2527 - 5917, Vol.2.

Habibie, M. N., Sasmito, A., \& Kurniawan, R. (2011). Kajian Potensi Energi Angin Di Wilayah Sulawesi Dan Maluku. Jurnal Meteorologi Dan Geofisika, 12(2), 181187.

Makhmudah, N. L., Subiki, \& Supeno. (2019). Pengembangan Modul Fisika Berbasisi Kearifan Lokal Permainan Tradisional Kalimantan Tengah Pada Materi Momentum dan Impuls. Jurnal Pembelajaran Fisika, 8, 181-186.

Mardotilah, F. (2016). Efektivitas Pembelajaran Fisika Menggunakan Lembar Kerja Siswa ( Lks ) Fisika Berbasis Kearifan. Jipf, 116-124

Mirza, Lubis, R.S., Gapy, M.(2019). Pemanfaatan Alternator Sebagai Pembangkit Listrik Tenaga Bayu (PLTB) KITEKTRO. Jurnal Online Teknik Elektro e-ISSN: 2252-7036 Vol.4 No.4: 19-24.

Novitasari, L., Agustina, P. A., Sukesti, R., \& Nazri, M. F. (2017). Makalah Pendamping ISSN : 2527-6670 Fisika, Etnosains, dan Kearifan Lokal dalam Pembelajaran Sains. 81-88.

Nurusholih, S., \& Permana, G. (2018). Aesthetic On The Kaulinan Of Sundanese, Kolecer. Balong International Journal of Design. https://doi.org/10.25134/balong.v1i1.16 67
Rosadi, P. R. E., Rapi, N. K., \& Yasa, P. (2019). Penerapan Bahan Ajar Sains Berbasis Kearifan Budaya Lokal Untuk Meningkatkan Aktivitas Dan Prestasi. 9(2), 75-84.

Satriawan, M., \& Rosmiati. (2016). Pengembangan Bahan Ajar Fisika Berbasis Kontekstual dengan Mengintegrasikan Kearifan Lokal untuk. Jurnal Penelitian Pendidikan Sains, 6(1).

Suastra, W. (2013). Model Pembelajaran Fisika Untuk Mengembangkan Kreativitas Berpikir Dan Karakter Bangsa Berbasis Kearifan Lokal Bali. JPI (Jurnal Pendidikan Indonesia), 2(2), 221-235.

Susanti, S., \& Nurtania, Y. (2017). Model Perilaku Komunikasi Komunitas Hong dalam Melestarikan Permainan dan Mainan Tradisional Sunda. Komuniti, 9(2), 126-145.

Utomo, P.(2017). Fisika Kelas X Gerak Melingkar Beraturan 136-192.

Wahyuni, S., Handhika, J., Kurniadi, E.(2019). Apersepsi Pencak Silat pada Materi Gelombang Bunyi untuk Pembelajaran Fisika .Lampung, 22-23 Oktober 2013

Yuliana.(2019). Upaya Meningkatkan Kreativitas Anak Melalui Permainan Baling-Baling Di Ra Attaqwa Karang Mulya Lampung Utara. skripsi Institut Agama Islam Negeri (IAIN) METRO. 
